\title{
PERENCANAAN PERHITUNGAN KEBUTUHAN BENANG PADA GARMEN T-SHIRT UNTUK GRAMASI KAIN YANG BERBEDA
}

\author{
Tina Martina 1), Annisa Tresnawardhani 1), Supandi 2) \\ 1) Program Studi Teknologi dan Bisnis Garmen \\ Sekolah Tinggi Teknologi Tekstil \\ 2) Program Studi Tata Busana \\ Fakultas Pendidikan Teknologi dan Kejuruan \\ Universitas Pendidikan Indonesia
}

\begin{abstract}
Abstrak. Perhitungan perencanaan kebutuhan benang jahit yang tepat, pada industri garmen akan memberikan gambaran kebutuhan benang sesuai dengan jumlah garmen yang dipesan. Jumlah kebutuhan benang jahit akan dipengaruhi oleh jenis serta gramasi kain yang berbeda. Penghematan benang pada proses penjahitan dapat dicapai dengan perhitungan kebutuhan benang pada perencanaan produksi yang lebih efisien. Tujuan penelitian ini adalah membuat perencanaan perhitungan kebutuhan benang untuk garmen $t$-shirt pada setiap mesin yang digunakan, dengan gramasi kain yang berbeda yaitu : $115 \mathrm{~g} / \mathrm{m}^{2}$ dan $145 \mathrm{~g} / \mathrm{m}^{2}$. Pengumpulan data dilakukan dengan mengukur panjang jahitan pada setiap proses yang ada hubungannya dengan penggunaan benang, kemudian hasil dari beberapa percobaan dirata-ratakan, dan dihitung sesuai perhitungan cara Coats. Kebutuhan benang pada produk T-shirt untuk gramasi kain $115 \mathrm{gram} / \mathrm{m}^{2}$ dibutuhkan benang 121 cone untuk spunpoly dan 138 cone untuk polyna. Pada gramasi kain $145 \mathrm{gram} / \mathrm{m}^{2}$ dibutuhkan 133 cone spunpoly dan 147 polyna
\end{abstract}

Kata kunci : kebutuhan benang jahit, coats, gramasi kain

\begin{abstract}
An accurate calculation of thread consumption will provide a right information of thread consumption based on the quantity of orders at garment industries. The number of thread consumption relates to fabric type and gramation. An accurate thread calculation will save thread usage in garment production. This research aims to plan and calculate the threads needed in T-shirt garment production using $115 \mathrm{~g} / \mathrm{m}^{2}$ and $145 \mathrm{~g} / \mathrm{m}^{2}$ fabric gramations. Data was collected through the measurument of the stitches length, which indicates the use of threads. The average results of several experiments were calculated according Coats method. It shows that T-shirts made of 115 $\mathrm{g} / \mathrm{m}^{2}$ fabric gramation needed 121 spunpoly thread cones and 138 polyna thread cones, while those made of $145 \mathrm{~g} / \mathrm{m}^{2}$ fabric gramation needed 133 spunpoly thread cones and 147 polyna thread cones.
\end{abstract}

Keyword : sewing thread consumption, coats, fabric gramation

\section{PENDAHULUAN}

Efisiensi material sangat penting dalam menunjang kelangsungan suatu industri garmen. Hampir $80 \%$ biaya produksi merupakan biaya pembelian material, sehingga diperlukan adanya manajemen perhitungan kebutuhan material yang akurat. Salah satu kebutuhan material yang dapat diefisienkan adalah kebutuhan benang. 
Perhitungan perencanaan kebutuhan material yang tepat pada industri garmen akan memberikan gambaran kebutuhan benang sesuai dengan jumlah garmen yang dipesan, dimana keubutuhan benang ini dipengaruhi oleh jenis serta gramasi kain yang berbeda. Kebutuhan benang pada suatu produk garmen sangan dipengaruhi oleh 5 faktor, yaitu: (1) kelas jahitan (seam); (2) jahitan per inci (stich per inchi/SPI); (3) ketebalan kain; (4) tegangan benang pada mesin jahit; dan (5) ketebalan benang jahit

Penghematan benang pada proses penjahitan dapat dicapai dengan perhitungan kebutuhan benang pada perencanaan produksi yang lebih efisien. Apabila perhitungan perencanaan kebutuhan benang tidak sesuai dengan kebutuhan produksi - pemborosan dapat berpengaruh pada keuntungan yang didapatkan oleh perusahaan - maka efisiensi perusahaan menurun. Perhitungan kebutuhan benang oleh bagian sample terkadang tidak sesuai dengan kebutuhan benang di bagian produksi, seperti terlihat pada Tabel 1.

Tabel 1. Perhitungan Kebutuhan Benang T-Shirt size L oleh bagian Sample

\begin{tabular}{ccccccccc}
\hline \multirow{2}{*}{$\begin{array}{c}\text { Total Qty } \\
\text { Garmen } \\
(\text { Pcs })\end{array}$} & $\begin{array}{c}\text { Kebutuhan } \\
(\text { meter })\end{array}$ & \multicolumn{2}{c}{$\begin{array}{c}\text { Kebutuhan } \\
(\text { cone })\end{array}$} & $\begin{array}{c}\text { Terima } \\
\text { oleh bag.produksi } \\
(\text { cone })\end{array}$ & $\begin{array}{c}\text { Kelebihan } \\
\text { bag.produksi } \\
(\text { cone })\end{array}$ \\
\cline { 2 - 9 } & Spunpoly & Polyna & Spunpoly & Polyna & Spunpoly & Polyna & Spunpoly & Polyna \\
\cline { 2 - 9 } 22.890 & 1.266 .366 & 1.354 .768 & 127 & 151 & 155 & 201 & 28 & 50 \\
\hline Ket?
\end{tabular}

Ket :

1 cone benang spunpoly : 10.000 meter

1 cone benang polyna : 9.000 meter

Dengan latar belakang diatas, maka penelitian ini bertujuan untuk membuat suatu perencanaan perhitungan kebutuhan benang untuk garmen $t$-shirt pada setiap mesin yang digunakan pada size L, untuk gramasi kain $115 \mathrm{~g} / \mathrm{m}^{2}$ dan $145 \mathrm{~g} / \mathrm{m}^{2}$ agar diperoleh efisiensi penyediaan benang yang sesuai dengan gramasi kain yang digunakan.

\section{Benang Jahit}

Benang jahit yang digunakan pada proses produksi sangat menentukan hasil akhir suatu seam. Pemilihan benang jahit yang benar harus disesuaikan dengan petunjuk kerja selama proses penjahitan, agar dapat diperoleh suatu jahitan dengan penampilan yang baik, maka diperlukan pemilihan benang jahit 
yang tepat. Penggunaan benang disesuaikan dengan jenis kain yang akan dijahit, ketebalan atau diameter benang dinyatakan sebagai nomor benang. Penomoran yang paling umum untuk benang sintetik dan benang core spun adalah Metric tiket number system, yang merupakan turunan dari sistem penomoran benang metrik $(=\mathrm{Nm})$. Penomeran dengan sistem metrik untuk benang jahit disebut Tkt, didasarkan kelipatan tiga dari sistim nomor metriknya.

\section{Jenis Stitch yang Digunakan pada order T-Shirt}

Jahitan atau stitch adalah kesatuan deret-deret yang diperoleh dari satu atau lebih benang yang dijeratkan. Jenis stitch yang dipakai pada penelitian ini, antara lain :

1. Kelas 300. Jahitan untuk kelas 300 dikenal juga jahitan lockstitch (jahitan kunci).jeratan kelas ini dibentuk oleh dua atau lebih kelompok benang dan karakteristik utamanya adalah interfacing.

2. Kelas 500. Jahitan kelas 500 adalah jahitan rantai tepi kain. Jeratn kelas ini dibentuk oleh satu kelompok benang atau lebih, dan mempunyai karakteristik umunya adalah paling sedikit salah satu kelompok benang menutupi atau membungkus pinggiran bahan. Jeratan ini mempunyai elastisitas yang tinggi dan tidak mudah terurai jeratannya. Kelas 500 ini memiliki pisau pemotong pada tepi mesinnya, sehingga sebelum kain dijahit, dipotong terlebih dahulu dan menghasilkan pinggiran yang rata. Beberapa mesin overlock menggunakan lima benang namun bisa juga menggunakan empat atau tiga benang, tergantung kebutuhannya. Ketika mesin berada dalam gerakan menjahit, pisau-pisau ini bergerak dalam gerakan menggunting dan membuang sisi pinggiran bahan yang berjumbai sehingga menghasilkan pinggiran bahan yang halus.

3. Kelas 600. Jahitan kelas 600 adalah jahitan rantai penutup pada permukaan bahan. Jeratan kelas ini dibentuk oleh tiga kelompok benang, dengan karakteristik umumnya adalah bahwa dua kelompok benang merupakan penutup kedua permukaan bahan. Lengkungan jeratan dari kelompok pertama dilewatkan menembus kain sambil masuk kedalam lengkungan jeratan dari kelompok ketiga yang berada di permukaan kain bagian atas 
kemudian melewati lengkungan jeratan kelompok kedua dan melakukan interlooping dengan kelompok benang kedua ini dibagian bawah kain. Adapun jenis stitch yang digunakan untuk order T-shirt terlihat pada Tabel 2, sedangkan jenis stitch yang digunakan pada setiap sambungan jahitan order tersebut terlihat pada gambar 1 .

Tabel 2 Jenis Stitch yang Digunakan pada T-Shirt

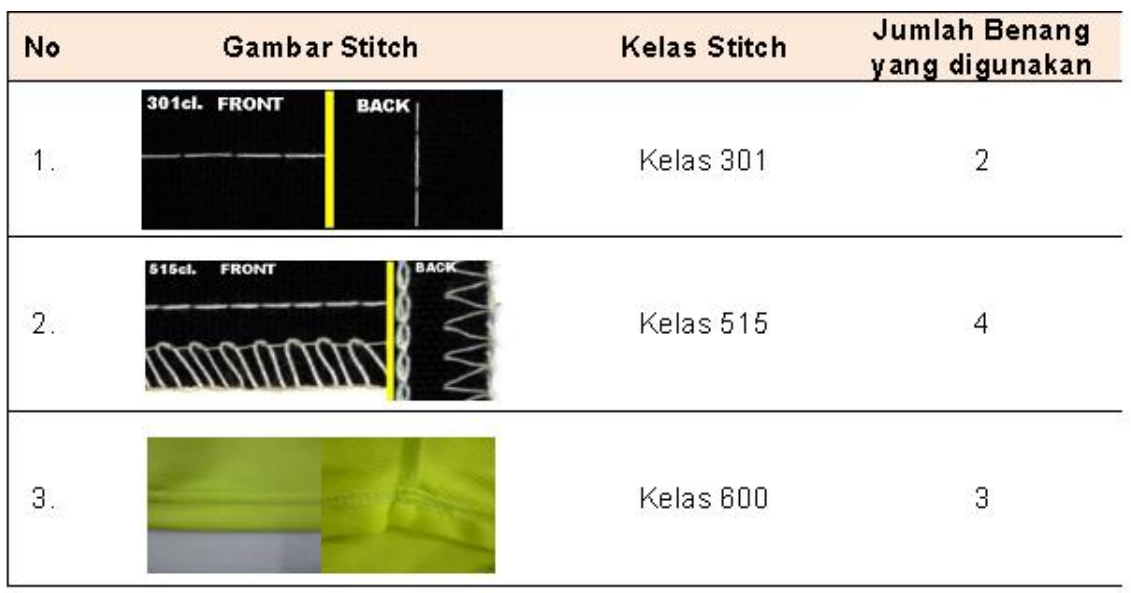

Sumber : STITCH and SEAM GUIDE to the ASTM Standard D-6193 (Formerly Federal Standard 751a)

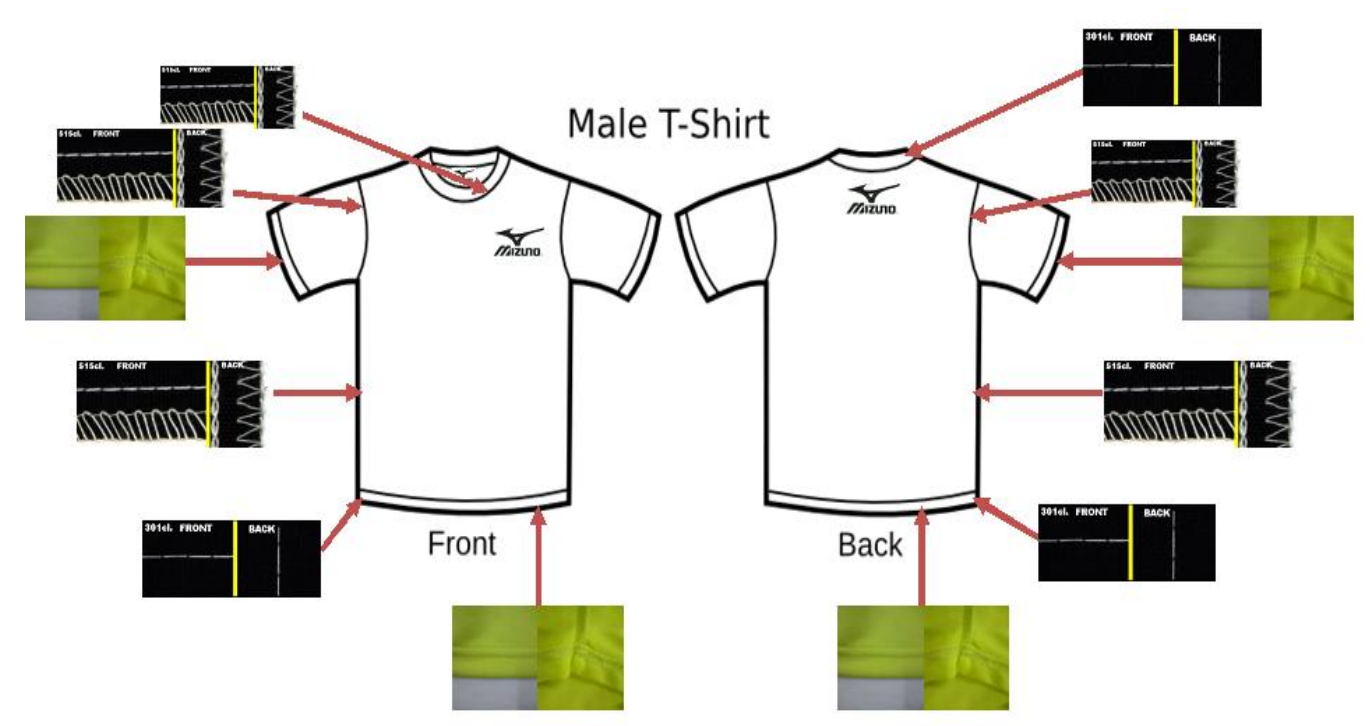

Gambar 2. Model T-Shirt dan jenis Stitch yang digunakan 


\section{Teknik Perhitungan Benang Coats}

Technical Bulletin yang dibuat oleh suplier benang Coats mengenai metode perhitungan kebutuhan benang untuk produksi garmen terdiri dari 3 metode, yaitu:

1. Mengukur jumlah aktual benang yang dikonsumsi dalam panjang tertentu pada suatu jahitan. Menghitung Kebutuhan benang yang dipakai dengan metoda penirasan benang pada panjang tertentu, seam dan stitch yang ditentukan (s), kemudian dikalikan dengan panjang jahitan (p) dan ditambahkan allowance sebesar $15 \%$.

Rumus :

Total Konsumsi Benang $=\mathrm{s}(\mathrm{cm}) \mathrm{p}(\mathrm{cm})+15 \%$ Allowance

2. Menggunakan rasio konsumsi kebutuhan benang. Menghitung kebutuhan benang dengan rasio kebutuhan benang, kemudian dikalikan dengan panjang jahitan yang dipakai.

Rumus: Total Konsumsi Benang $(\mathrm{cm})=($ Panjang Jahitan $(\mathrm{cm}) \times$ Ratio $) \times \%$ benang

Tabel 3. Rasio Kebutuhan Benang Metode Coats

\begin{tabular}{llccc}
\hline Kelas & \multicolumn{1}{c}{ Jenis Mesin } & $\begin{array}{c}\text { Total } \\
\text { Pemakaian } \\
\text { Benang } \\
(\mathrm{cm})\end{array}$ & $\begin{array}{c}\text { \% Benang } \\
\text { Jarum }\end{array}$ & $\begin{array}{c}\text { \% Benang } \\
\text { Looper atau } \\
\text { Benang } \\
\text { bawah }\end{array}$ \\
\hline 301 & Lockstich & 2,5 & $50 \%$ & $50 \%$ \\
101 & Chainstitch & 4,0 & $100 \%$ & - \\
401 & 2 Thread Chainstitch & 5,5 & $25 \%$ & $75 \%$ \\
304 & Zig-Zag Lockstitch & 7,0 & $50 \%$ & $50 \%$ \\
503 & 2 Thread Overlock & 12,0 & $55 \%$ & $45 \%$ \\
504 & 3 Thread Overlock & 14,0 & $20 \%$ & $80 \%$ \\
512 & 4 Thread Safety stitch & 18,0 & $25 \%$ & $75 \%$ \\
516 & 5 Thread Safety stitch & 20,0 & $20 \%$ & $80 \%$ \\
406 & 3 Thread Covering & 18,0 & $30 \%$ & $70 \%$ \\
& stitch & & & $80 \%$ \\
602 & 4 Thread Covering & 25,0 & $20 \%$ & $70 \%$ \\
& stitch & & & \\
\hline
\end{tabular}


Sebagai supplier besar benang jahit Coats mempunyai standar rasio kebutuhan benang yang dapat digunakan untuk menghitung jumlah benang yang harus dipesan dalam memenuhi order di industri garmen, hal ini terlihat pada Tabel 3

\section{METODOLOGI PENELITIAN}

Penelitian ini mengambil obyek order T- Shirt dengan jumlah order 22.890 pcs, sehingga perhitungan kebutuhan benangnya disesuaikan dengan jumlah pesanan. Ketebalan jahitan (seam) yang digunakan dalam penjahitan suatu produk garmen sangat berpengaruh pada kebutuhan benang yang digunakan, hal ini dapat dianalogkan jika material yang digunakan gramasinya lebih besar maka, ketebalan seam yang digunakan menjadi lebih besar, sehingga kebutuhan benang lebih banyak.

Penghematan kebutuhan benang dapat dilakukan dengan cara menghitung secara akurat kebutuhan benang berdasarkan faktor perhitungan yang sesuai standar serta memberikan angka kelonggaran yang tepat sehingga tidak mengganggu jalannya produksi. Prosedur penelitian ini mengikuti langkahlangkah seperti pada gambar 1 .

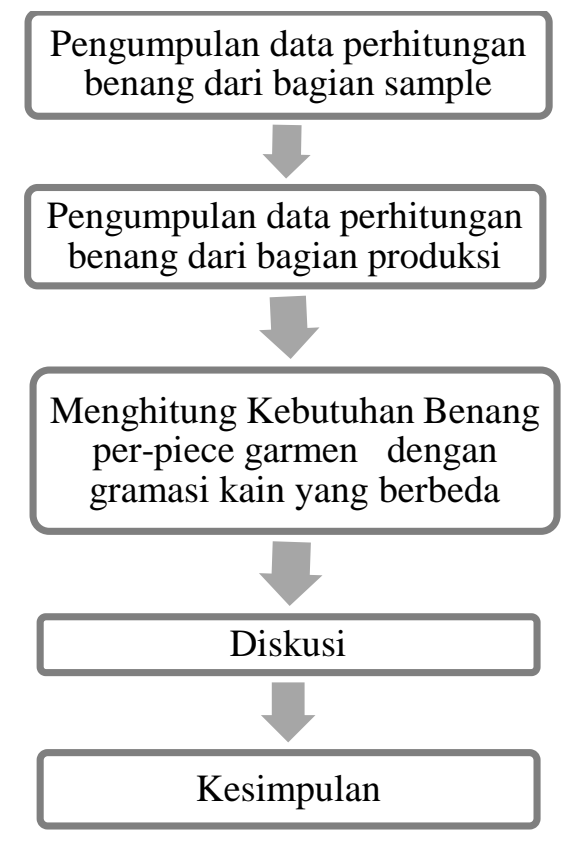

Gambar 1 Diagram Alir Penelitian Perhitungan Kebutuhan Benang

Penelitian diawali dengan proses pengumpulan data perhitungan benang dari bagian sample, kemudian dilanjutkan dengan pengumpulan data perhitungan 
benang dari bagian produksi. Setelah itu dilakukan perhitungan kebutuhan benang per-piece garmen dengan gramasi kain yang berbeda.

Pengumpulan data diperlukan untuk membuat perencanaan kebutuhan benang yang sesuai serta mengetahui jenis-jenis seam yang digunakan pada $T$ shirt, dengan gramasi kain yang berbeda. Mesin-mesin yang digunakan untuk memproduksi style tersebut adalah: mesin Lockstitch with automatic thread trimmer type Juki DDL-5550-3, Needle Overlock type Pegasus EX-5214M53/333, dan mesin Overdeck 2 needle type pegasus W 664-0.

Teknik pengumpulan data yang dilakukan sesuai dengan cara perhitungan benang menurut metode Coats, yaitu: (1) mengukur jumlah aktual benang yang digunakan dari jahitan; (2) menggunakan rasio konsumsi kebutuhan benang; dan (3) menggunakan rata-rata konsumsi benang.

Teknik pengumpulan data yang diambil adalah mengukur jumlah aktual benang yang dikonsumsi dalam panjang tertentu pada suatu jahitan. Pengumpulan data dilakukan dengan mengukur panjang jahitan pada setiap proses yang ada hubungannya dengan penggunaan benang, kemudian hasil dari beberapa percobaan dirata-ratakan, kemudian dihitung sesuai dengan standar perhitungan metode Coats.

\section{Metoda Perhitungan Kebutuhan Benang Jahit}

Metoda yang dilakukan sesuai dengan metoda Coats, yaitu mengukur kebutuhan benang dari hasil penirasan benang sepanjang 1 inch, ditambahkan nilai kelonggarannya pada setiap jahitan komponen. Perhitungan kebutuhan benang berkaitan dengan tahapan proses jahit dari garmen tersebut, hasil dari penelitian tiras benang yang dilakukan kemudian dikalikan dengan panjang garmen tiap proses. Rincian metoda penelitian tiras benang sebagai berikut :

1. Penelitian dilakukan pada kain rajut gramasi $115 \mathrm{gram} / \mathrm{m}^{2}$ dan gramasi 145 gram $/ \mathrm{m}^{2}$, dengan produk $t$-shirt, penelitian dilakukan dengan cara mengukur jarak pemakaian benang produk $t$-shirt pada setiap proses jahitan. Dengan memperhatikan mesin yang dipakai dan jenis jahitan yang digunakan.

2. Perhitungan yang dilakukan adalah : 
a. Menjahit sesuai dengan seam (jenis jahitan) yang terdapat dalam produk tersebut. Memotong jahitan tersebut dengan ukuran panjang jahitan per 1 inch sebanyak 20 contoh uji.

b. Mengurai jahitan tersebut secara teliti.

c. Menghitung panjang benang yang terdapat pada jahitan tersebut.

d. Menghitung kebutuhan benang pada setiap mesin yang digunakan pada $t$ shirt dengan standar perhitungan Kebutuhan benang yang akurat dengan sistem perhitungan kebutuhan benang dari Coats.

\section{HASIL DAN PEMBAHASAN}

\section{Perhitungan aktual hasil pengujian}

Tabel 4. Hasil Perhitungan Kebutuhan Benang Pada Mesin Overlock Dengan Ketebalan Kain 1,756 mm dan 2,164 mm

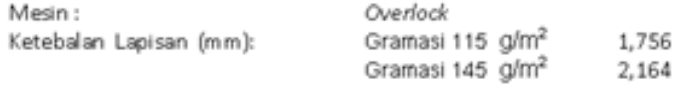

\begin{tabular}{|c|c|c|c|c|c|c|c|}
\hline \multicolumn{4}{|c|}{ Gramad $115 \mathrm{~g}^{\prime} \mathrm{m}^{2}(\mathrm{~cm})$} & \multicolumn{4}{|c|}{ Gram as $145 \mathrm{~g} / \mathrm{m}^{2}(\mathrm{~cm})$} \\
\hline $\begin{array}{c}\text { Benang stas } \\
1\end{array}$ & $\begin{array}{c}\text { Benang atas } \\
2\end{array}$ & $\begin{array}{c}\text { Benangbawah } \\
1\end{array}$ & $\begin{array}{l}\text { Bensngbawah } \\
2\end{array}$ & $\begin{array}{c}\text { Benang atas } \\
1\end{array}$ & $\begin{array}{c}\text { Benangatas } \\
2\end{array}$ & $\begin{array}{c}\text { Bensng bawsh } \\
1\end{array}$ & $\begin{array}{c}\text { Bensong bawsh } \\
2\end{array}$ \\
\hline 7,2 & 8,8 & 16,5 & 20 & 7,6 & 11,8 & 19,5 & 20,6 \\
\hline 7,2 & 6,3 & 18,5 & 21 & 6.7 & 10,3 & 19,5 & 22,6 \\
\hline 6,5 & 8 & 17 & 20 & 7,6 & 11,6 & 20 & 22 \\
\hline 6,5 & 8 & 18 & 20,6 & 7,5 & 10,8 & 21 & 20 \\
\hline 5,5 & 7,5 & 17 & 20 & 7,6 & 11,4 & 21,5 & 21,7 \\
\hline 6,5 & 8,5 & 18,5 & 20,3 & 7,8 & 11,8 & 21 & 20 \\
\hline 6,5 & 8 & 18,5 & 21 & 7,3 & 10,7 & 21 & 18 \\
\hline 6,5 & 8,3 & 17,3 & 21 & 8 & 11,7 & 21,5 & 22 \\
\hline 6,5 & 8,5 & 18,5 & 22,5 & 7,7 & 11,7 & 22 & 22,4 \\
\hline 6,5 & 8,5 & 17 & 22 & 7 & 11,3 & 19,8 & 21,8 \\
\hline 6,5 & 8,3 & 17 & 21,5 & 8,3 & 12,7 & 19,7 & 22 \\
\hline 6,5 & 8,5 & 17,5 & 21 & 7,2 & 10 & 19,5 & 20,5 \\
\hline 6,2 & 8,5 & 18 & 22 & 7,5 & 12,3 & 22 & 22,5 \\
\hline 6,3 & 7 & 16,5 & 21,5 & 8 & 12 & 22 & 22 \\
\hline 6,5 & 8,5 & 18,5 & 22 & 7,7 & 12,2 & 19,7 & 22 \\
\hline 6,5 & 7,5 & 16,5 & 20 & 7 & 10,7 & 19,8 & 21,5 \\
\hline 7,2 & 8,5 & 17,3 & 21 & 7,6 & 11,8 & 21,5 & 20 \\
\hline 7 & 8 & 16,8 & 22 & 7,4 & 11,2 & 21,2 & 21,5 \\
\hline 7 & 8 & 17 & 21 & 7,2 & 11,5 & 22,1 & 20 \\
\hline 7,1 & 8,2 & 16,5 & 21,5 & 7,5 & 11,4 & 19,8 & 21,3 \\
\hline 6,61 & 8,07 & 17,42 & 21,095 & 7,51 & 11,445 & 20,705 & 21,22 \\
\hline
\end{tabular}

Perhitungan hasil pengujian kebutuhan benang berdasarkan gramasi kain yang berbeda disajikan pada Tabel 4 sampai Tabel 6. Proses penjahitan komponen menggunakan 2 jenis benang yaitu benang spunpoly dan polyna. Benang atas menggunakan benang spunpoly dan benang bawah (bobbin) dan looper menggunakan benang polyna, kecuali pada proses penjahitan kelim dengan menggunakan mesin Overdeck, benang atas dan benang bawah menggunakan benang spunpoly. 
Tabel 5. Hasil Perhitungan Kebutuhan Benang Pada Mesin Overlock dengan Ketebalan Kain 1,334 mm dan 2,654 mm

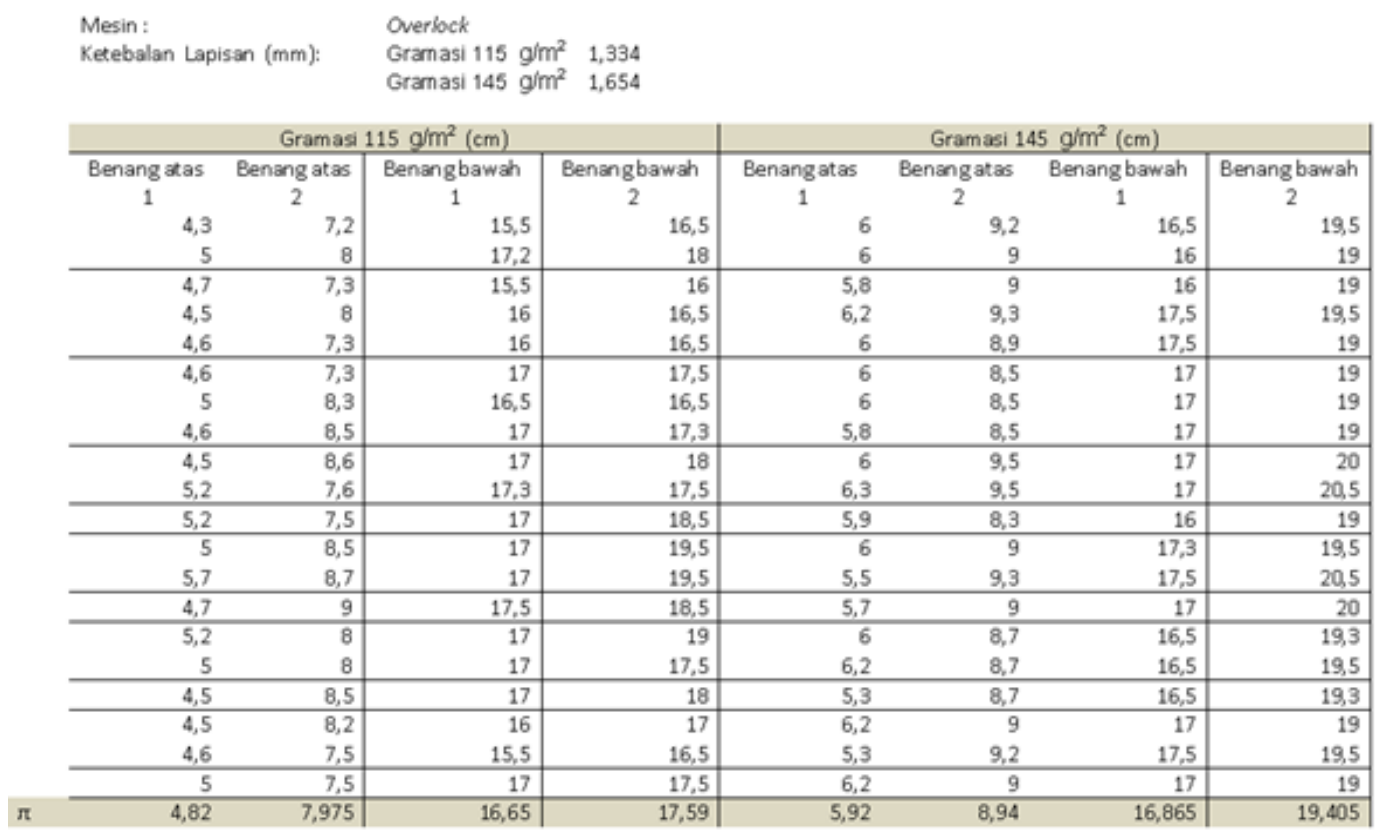

Tabel 6. Hasil Perhitungan. Kebutuhan Benang Pada Mesin Overlock Dengan Ketebalan Kain 1,162 mm dan $1.37 \mathrm{~mm}$

\begin{tabular}{|c|c|c|c|c|c|c|}
\hline & \multicolumn{2}{|c|}{$\begin{array}{l}\text { Mesin: } \\
\text { Ketebal an Lapisan }(\mathrm{mm}) \text { : }\end{array}$} & $\begin{array}{l}\text { Overdeck } \\
\text { Gramasi } 115 \mathrm{~g} / \mathrm{m}^{2} \\
\text { Gramasi } 145 \mathrm{~g} / \mathrm{m}^{2}\end{array}$ & $\begin{array}{ll}2 & 1,162 \\
2 & 1,37\end{array}$ & & \\
\hline & \multicolumn{3}{|c|}{ Gramasi $115 \mathrm{~g} / \mathrm{m}^{2}(\mathrm{~cm})$} & \multicolumn{3}{|c|}{ Gramasi $145 \mathrm{~g} / \mathrm{m}^{2}(\mathrm{~cm})$} \\
\hline & Benang atas 1 & Benang atas 2 & Benang bawah & Benang atas 1 & Benang atas 2 & Benang baw ah \\
\hline & 5,2 & 7 & 21 & 5,5 & 7,2 & 21,5 \\
\hline & 5,2 & 7,3 & 21,5 & 5,6 & 7 & 22,2 \\
\hline & 5,3 & 7 & 20,5 & 6,2 & 7,2 & 22 \\
\hline & 5,3 & 7 & 20 & 6,1 & 7,2 & 22 \\
\hline & 5,2 & 7,2 & 20 & 6 & 7,2 & 22,3 \\
\hline & 5,2 & 7,1 & 21 & 6 & 7,2 & 22 \\
\hline & 5,2 & 7,2 & 20 & 6,1 & 7,2 & 21,5 \\
\hline & 5,2 & 7,3 & 20 & 6,1 & 7,3 & 21,5 \\
\hline & 5,5 & 7,2 & 21,5 & 5,5 & 7,3 & 21 \\
\hline & 5,3 & 7,2 & 21 & 6 & 7,2 & 22 \\
\hline & 5,1 & 7,3 & 20 & 6,5 & 7,4 & 22 \\
\hline & 5,2 & 7,3 & 21 & 6,5 & 7,4 & 22 \\
\hline & 5,5 & 7,5 & 22 & 6 & 7,5 & 22,5 \\
\hline & 6 & 7,7 & 21,5 & 6,2 & 7,7 & 23 \\
\hline & 5,3 & 7,3 & 21 & 6,5 & 8 & 23,5 \\
\hline & 5,2 & 7,3 & 21 & 5,5 & 7,5 & 22 \\
\hline & 5,3 & 7 & 20,7 & 5,5 & 7,5 & 22 \\
\hline & 5,3 & 7 & 20,5 & 5,7 & 7,5 & 22 \\
\hline & 5,3 & 7 & 20 & 6 & 7,5 & 21,5 \\
\hline & 6 & 7,5 & 21,5 & 6,5 & 7,5 & 22,5 \\
\hline$\pi$ & 5,34 & 7,22 & 20,785 & 6 & 7,375 & 22,05 \\
\hline
\end{tabular}




\section{Perencanaan Kebutuhan Benang}

Prinsip manajemen persediaan adalah suatu konsep dalam manajemen produksi/ operasi yang membahas tentang cara yang tepat dalam perencanaan kebutuhan bahan baku dalam proses produksi, sehingga bahan yang dibutuhkan dapat tersedia sesuai dengan yang direncanakan. Hal ini menjelaskan bahwa perlu adanya perhitungan kebutuhan barang dalam pemenuhan produksi, perencanaan yang tepat akan meminimalisir persediaan, dimana pembelian bahan dilakukan sebatas yang diperlukan saja. Suatu perencanaan seharusnya didasarkan pada cara perhitungan yang sesuai dan harus diperbaharui setiap muncul variasi yang berbeda, misalkan pada gramasi kain yang berbeda.

Tabel 7. Perbandingan Kebutuhan Benang pada Gramasi kain 115 g/m² dan 145 $\mathrm{g} / \mathrm{m}^{2}$

\begin{tabular}{cccc}
\hline \multicolumn{2}{c}{ Gramasi $115 \mathrm{~g} / \mathrm{m}^{2}$} & \multicolumn{2}{c}{ Gramasi $145 \mathrm{~g} / \mathrm{m}^{2}$} \\
Spunpoly (cone) & Polyna (cone) & Spunpoly (cone) & Polyna (cone) \\
\hline \multirow{2}{*}{121} & 138 & 133 & 147 \\
\hline
\end{tabular}

Berdasarkan tabel 7 menunjukan bahwa dengan perbedaan gramasi kain dapat berpengaruh pada kebutuhan benang, hal ini sesuai dengan teori, bahwa bahwa faktor ketebalan lapisan jahitan (seam) berpengaruh dengan kebutuhan benang yang yang digunakan, dapat dianalogikan jika material memiliki gramasi kain yang lebih besar maka seam yang dibentuk akan lebih tebal sehingga kebutuhan benang akan lebih banyak. Perusahaan garmen seharusnya mempertimbangkan ketebalan seam yang digunakan pada garmen, sehingga perencanaan kebutuhan benang lebih akurat. Grafik perbandingan kebutuhan benang berdasarkan gramasi yang berbeda dilampirkan pada Gambar 2 .

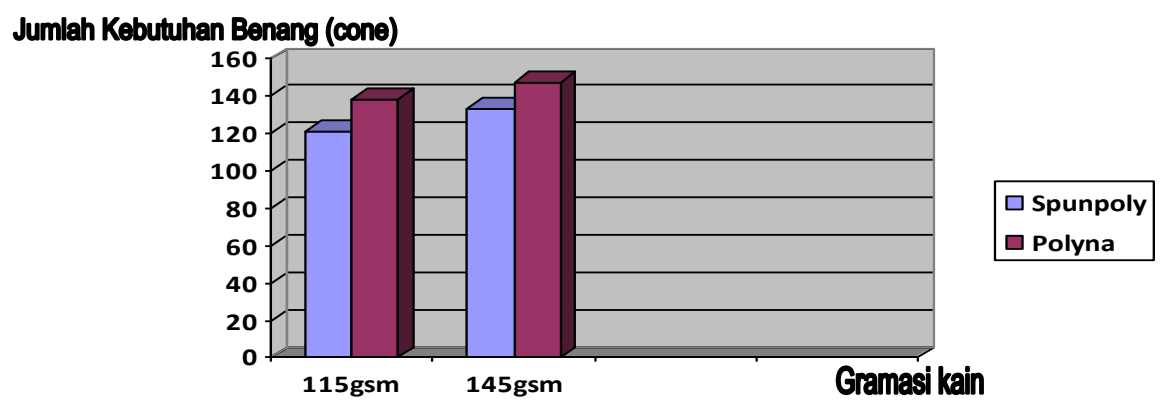

Gambar 3. Perbandingan Kebutuhan Benang dengan Gramasi kain yang Berbeda 


\section{KESIMPULAN}

1. Dari hasil perhitungan diperoleh kebutuhan benang pada produk T-shirt untuk gramasi kain 115 gram $/ \mathrm{m}^{2}$ dibutuhkan benang 121 cone untuk spunpoly dan 138 cone untuk polyna. Pada gramasi kain 145 gram $/ \mathrm{m}^{2}$ dibutuhkan 133 cone spunpoly dan 147 polyna.

2. Persentasi perbedaan kebutuhan benang pada gramasi $115 \mathrm{gram} / \mathrm{m}^{2}$ dan 145 gram $/ \mathrm{m}^{2}$ sebesar $10 \%$ untuk spunpoly dan $5,8 \%$ untuk polyna.

3. Persentasi kebutuhan benang hasil penelitian dengan perhitungan kebutuhan benang PT PFG sebesar $28 \%$ untuk spunpoly dan $46 \%$ untuk polyna.

\section{DAFTAR PUSTAKA}

Annisa Tresnawardhani, Perencanaan Perhitungan Kebutuhan Benang Pada Garmen T-Shirt Untuk Gramasi Kain Yang Berbeda

American and Effird,Estimating Thread Consumption, www.google.com/americanandeffird/technicalbuletin (diakses pada tanggal $14 \mathrm{Mei} 2011$ )

AOTS, Pegasus technical training course, 2005

Coats,Thread Consumption Guide,www.coatsindia.com

Harold, Carl The Technology of clothing manufacture ${ }^{2 n d}$ Edition

Yamit, Zulian, Manajemen Persediaan, Yogyakarta, 2008

6193

Stitch and Seam Guide to the ASTM Standard D- 